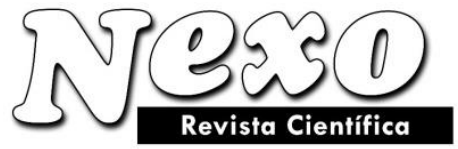

Universidad Nacional de Ingeniería COPYRIGHT @ (UNI). TODOS LOS DERECHOS RESERVADOS
http://revistas.uni.edu.ni/index.php/Nexo https://doi.org/10.5377/nexo.v34i02.11559

Vol. 34, No. 02, pp. 744-758/Junio 2021

\title{
Resistive maintenance and equipment criticality indexes
}

\section{Índices de criticidad de equipos y mantenimiento resistivo}

\author{
Seyed Mohammad Seyed Hosseini*, Kamran Shahanaghi, Safar Shasfand \\ Iran University of Science and Technology, Tehran, Iran. \\ * seyedhosseini@iust.ac.ir
}

(recibido/received: 05-enero-2021; aceptado/accepted: 28-marzo-2021)

\begin{abstract}
Optimum maintenance of hundreds of thousands of equipment used by each company is one of the main challenges of maintenance, operation, and procurement managers. Continuous production and competition in the business environment and resource constraints require that the vital equipment of each company must be controlled, monitored, and considered. To do this, identifying critical and essential equipment is necessary. In this paper, a formula was defined by field surveys and preferences of 75 petrochemical industry experts and managers to determine the equipment sensitivity index. Experts' opinions extracted ten compelling features in determining the sensitivity of the equipment, and the weighting coefficient of each one was obtained by using the group decision-making method, Analytical Hierarchy Process. The introduction of the resistive maintenance index formula represents the capability to use strengths and opportunities and sustainability and resistance against weaknesses and threats. The original formula has five sub-indicators consisting of equipment effectiveness, labor effectiveness, cost efficiency, degree of endogeneity, extraversion and exogeneity, and the rate of health, safety, and environmental events. From the perspective of 64 specialists, the group decision-making method and paired comparison matrix were used to determine their weighting coefficient.
\end{abstract}

Keywords: Sensitivity Index, Critical Equipment, Resistive Index, Expert's Preferences, Group Decision Making.

\section{RESUMEN}

El mantenimiento óptimo de cientos de miles de equipos utilizados por cada empresa es uno de los principales desafíos de los gerentes de mantenimiento, operación y adquisiciones. La producción continua y la competencia en el entorno empresarial y las limitaciones de recursos requieren que los equipos vitales de cada empresa deben ser controlados, monitoreados $\mathrm{y}$ considerados. Para hacer esto, es necesario identificar equipos críticos y esenciales. En este trabajo, se definió una fórmula mediante encuestas de campo y preferencias de 75 expertos y gerentes de la industria petroquímica para determinar el índice de sensibilidad de los equipos. Las opiniones de los expertos extrajeron diez características convincentes para determinar la 
sensibilidad del equipo, y el coeficiente de ponderación de cada uno se obtuvo utilizando el método de toma de decisiones grupales, Proceso de Jerarquía Analítica. La introducción de la fórmula del índice de mantenimiento resistivo representa la capacidad de utilizar las fortalezas y oportunidades y la sostenibilidad y resistencia contra debilidades y amenazas. La fórmula original tiene cinco subindicadores que consisten en la efectividad de los equipos, la efectividad de la mano de obra, la eficiencia de costos, el grado de endogeneidad, la extraversión y exogeneidad, y la tasa de eventos de salud, seguridad y ambientales. Desde la perspectiva de 64 especialistas, se utilizó el método de toma de decisiones grupales y la matriz de comparación pareada para determinar su coeficiente de ponderación.

Palabras clave: Índice de sensibilidad, Equipo crítico, Índice resistivo, preferencias del experto, Toma de decisiones en grupo.

\section{INTRODUCTION}

There are fundamental challenges in investigating objective evidence and existing documentation in the oil, gas, and petrochemical industry. Abnormal safety events, environmental problems, hard working conditions, and inappropriate combination of human resources, lack of access to critical spare parts, production with lower capacity, the impossibility of upgrading control systems and accurate tools, restriction on the use of technology due to sanctions, and hundreds of billions of dollars have been invested in facilities and equipment of Iranian oil industry. On the other hand, to optimizeand enhance existing facilities, at least 205 billion $\$$ in investments (Bitaraf, 2017) in the sixth development plan is required. Nowadays, using excellence models is essential to improve productivity (Sivaram, 2013) and safeguard the national capital. Therefore, researchers in the study have designed resistive maintenance along with resistive economics and production (Shasfand \& Seyed Hosseini, 2016) Benchmarking, (Wireman, 2004), the use of superior experiences) Stevens, 2017), indexing (Parida, 2015), evaluation of trends, Integration between (Wang, 2011), Cost effect (Zuashkiani, 2011) can be effective in improving the inclusive maintenance (Seyed Hosseini, 2011). The effectiveness of these approaches is assessed by the reliability indicators (MTBF) (Shasfand, 2017), availability (MTTR) (Charaf \& Ding, 2015), the percentage of implementation of PM (Preventive maintenance) programs, and the rate of emergency maintenance (Assaf, 2014), defined in the strategic management process (Sivaram, 2013) as well as the quality of the maintenance activities. In the vibration measurement and analysis of the vibrations, to reduce emergency stops and increase the reliability of very sensitive equipment, rotary machines, the CM (Condition Monitoring) approach is used. In this regard, the authors of the paper introduce two formulas of Equipment Sensitivity Index and Resistive Maintenance Index.

\section{A REVIEW OF PREVIEW OF PREVIOUS STUDIES}

Since the subjects of the resistive economy and, consequently, the resistive production and the maintenance are the new debates, they have not been directly studied or at least researches in this field are not available for now. As a result, researchers have used related and updated papers. Four hundred fifty-eight articles on maintenance issues were published in internationally authorized journals from 1995 to 2019 , and the concepts raised by the authors, along with their repeatability, were listed in Table $1.40 \%$ of authors have mentioned preventive maintenance directly and indirectly. Preventive maintenance is the core concept of maintenance. Preventive 
Maintenance, Maintenance management, cost, reliability, and condition-based maintenance are five major maintenance's elements (Table 1).

Table 1: The top 20 concepts of maintenance in 458 reviewed articles

\begin{tabular}{|l|l|l|}
\hline No. & \multicolumn{1}{|c|}{ Item } & Rep. \\
\hline 1 & Preventive Maintenance (PM) & 120 \\
\hline 2 & Maintenance Management & 106 \\
\hline 3 & Cost & 95 \\
\hline 4 & Reliability , Availability \& Maintainability(RAM) & 81 \\
\hline 5 & Condition Based Maintenance (CBM) & 72 \\
\hline 6 & Reliability Centered Maintenance (RCM) & 66 \\
\hline 7 & Total Productive Maintenance (TPM) & 64 \\
\hline 8 & Strategy & 58 \\
\hline 9 & Risk & 56 \\
\hline 10 & Failure Mode Effect Analysis (FMEA) \& RCA & 51 \\
\hline 11 & Safety & 51 \\
\hline 12 & Control & 47 \\
\hline 13 & Risk Based Inspection (RBI) & 46 \\
\hline 14 & Overall Equipment Effectiveness (OEE) & 46 \\
\hline 15 & Process & 43 \\
\hline 16 & Tactics & 42 \\
\hline 17 & Key Performance Indicators (KPI ${ }_{\text {s }}$ ) & 41 \\
\hline 18 & Computerized Maintenance Management System (CMMS) & 37 \\
\hline 19 & Life Cycle Cost (LCC) & 34 \\
\hline 20 & Material (Spare Parts) & 31 \\
\hline
\end{tabular}

The author of the article attended the comprehensive training course on productive maintenance management in Samsung's Cheil petrochemical Company which has won TPM Award in 2000, for 18 days in November 2001. The prioritization of equipment was carried out by two groups of maintenance and operation in the company. Judgment of the maintenance department was based on the type of failure, the efficiency of repairs, and serviceability according to (Table 2) and the production group judged the indicators of safety, environment, production, and quality according to (Table 3) (Shasfand \& Alipour, 2003). The two groups are summarized in (Table 4) and the type of maintenance (Time Based Maintenance, Condition Based Maintenance, Break down Maintenance) is specified based on it.

Table 2: Judgment of the maintenance department

\begin{tabular}{|l|l|l|l|}
\hline Row & \multicolumn{1}{|c|}{3} & \multicolumn{1}{|c|}{2} & \multicolumn{1}{|c|}{1} \\
\hline Abrasive $* \mathbf{5}$ & High speed of abrasive & Low speed & Very low speed \\
\hline Maintenance efficiency $* \mathbf{5}$ & No spare parts & $\begin{array}{l}\text { Need to vendor } \\
\text { service }\end{array}$ & Easy maintenance \\
\hline Treatment $* \mathbf{3}$ & $\begin{array}{l}\text { High temperature \& Pressure, } \\
\text { difficult handling }\end{array}$ & Medium & Low \\
\hline
\end{tabular}


Table 3: Judgment by production team

\begin{tabular}{|l|l|l|l|}
\hline Row & \multicolumn{1}{|c|}{3} & \multicolumn{1}{c|}{2} & \multicolumn{1}{c|}{1} \\
\hline Safety $* 5$ & Big trouble & Middle trouble & Common trouble \\
\hline Environment $* 4$ & Big trouble & Middle trouble & Common trouble \\
\hline Production $* 5$ & S/D over than $1 \mathrm{hr}$. & S/D below than 1 hour & Not loss production only stooped \\
\hline Quality $* 4$ & Cost $>17000 \$$ & $250 \$<$ cost $<17000 \$$ & Cost $<250 \$$ \\
\hline
\end{tabular}

Table 4: Degree of critical

\begin{tabular}{|l|c|c|c|c|}
\hline \multirow{2}{*}{ Maintenance judgment } & \multicolumn{4}{|c|}{ Production judgment } \\
\cline { 2 - 5 } & $\mathrm{A}(34-54)$ & $\mathrm{B}(27-33)$ & $\mathrm{C}(22-26)$ & $\mathrm{D}(18)$ \\
\hline $\mathrm{A}(33-39)$ & $\mathrm{A}$ & $\mathrm{A}$ & $\mathrm{B}$ & $\mathrm{B}$ \\
\hline $\mathrm{B}(23-31)$ & $\mathrm{A}$ & $\mathrm{B}$ & $\mathrm{C}$ & $\mathrm{C}$ \\
\hline $\mathrm{C}(16-21)$ & $\mathrm{B}$ & $\mathrm{C}$ & $\mathrm{C}$ & $\mathrm{D}$ \\
\hline $\mathrm{D}(13)$ & $\mathrm{B}$ & $\mathrm{C}$ & $\mathrm{C}$ & $\mathrm{D}$ \\
\hline
\end{tabular}

The performances of the maintenance were examined in a study by (Simoes, 2011) on 251 published articles from 1997 to 2009.The result of their review indicates that the various criteria have been reviewed 345 times in the articles and some of them have been repeated several times. For example, the cost element has been raised in 40 papers. The 36 main indicators with the number of iterations are extracted in (Table 5).

Table 5: Criteria outlined in 251 papers reviewed by Simoes, J.M., et.al.

\begin{tabular}{|l|l|c|l|l|c|l|l|l|}
\hline No. & Item & Rep. & $\begin{array}{l}\text { N } \\
\text { o. }\end{array}$ & Item & Rep. & No. & Item & Rep. \\
\hline 1 & Cost & 40 & 13 & Reliability & 10 & 25 & Tools & 4 \\
\hline 2 & OEE & 34 & 14 & Productivity & 10 & 26 & Time & 4 \\
\hline 3 & Availability & 31 & 15 & Spare Parts & 9 & 27 & Service level & 4 \\
\hline 4 & Quality & 21 & 16 & Maintenance strategies & 9 & 28 & Man power & 4 \\
\hline 5 & MTBF & 17 & 17 & Human Resource & 8 & 29 & Inventory Cost & 4 \\
\hline 6 & Tasks & 15 & 18 & PM & 7 & 30 & MTTF & 3 \\
\hline 7 & MTTR & 15 & 19 & Maintenance Organization & 6 & 31 & Flexibility & 3 \\
\hline 8 & Material & 14 & 20 & Down time cost & 6 & 32 & Events & 3 \\
\hline 9 & Equipment & 13 & 21 & Defect & 6 & 33 & Efficiency & 3 \\
\hline 10 & Downtime & 13 & 22 & Labour Cost & 5 & 34 & Delivering & 3 \\
\hline 11 & labour & 11 & 23 & Equipment Losses & 5 & 35 & Break downs & 3 \\
\hline 12 & Failures & 11 & 24 & Accidents & 5 & 36 & BM & 3 \\
\hline
\end{tabular}

Data Envelopment Analysis (DEA) model was used by Assaf, S.A et al. (2014) in an article on the evaluation of performance and alignment to measure performance and alignment in Saudi Arabia's petrochemicals (Assaf, 2014).

Key indicators in a thermal power plant were investigated by (Lindberg 2015). According to them, the existence of key indicators causes improvement in maintenance performance.

(Kareem \& Jewo, 2015) the developed mathematical model in Nigeria's petrochemical industry 
for predicting equipment failure. The proposed framework is based on temperature, pressure, and vibration parameters, through which the failure occurrence time can be predicted. They investigated Warri petrochemical and refinery equipment in Nigeria. The formula follows the reliability, and the family of Weibull models is one of the most widely used models in the reliability (Blischke \& Murthy, 2003). The reliability is calculated by the failure rate obtained for any equipment duration of turbine performance, which was defined as 43800 hours, and by using the formula 1:

$$
R(t)=e^{-\lambda t}=e^{-\frac{t}{m t b f}}
$$

(Chia Chien, 2007) integrate principles and methods of TPM and RCM and uses different tools to support decision-makers and operators. RCM and TPM require the maintenance and production departments to operate synergistically in order to discern and avoid potential problems.

The findings by Shahin, A. et al. (2018) indicate that the design out maintenance (DOM), business-centered maintenance (BCM), risk-based maintenance (RBM), and accessibilitycentered maintenance (ACM) tactics with weights of $0.86,0.94,0.68$, and 1.00 are located at the corners of the Decision Making Grid (DMG), respectively. The two remaining tactics, total productive maintenance (TPM) and reliability-centered maintenance (RCM) are located at the middle corners. Also, the results indicate that the share of tactics per spotted equipment in the grid as 62, 22, and 16 percent for RCM, DOM and BCM, respectively (Shahin, 2018).

Risk-based maintenance (RBM) is among the most advanced comprehensive risk assessment methodologies for the criticality analysis of assets. The study by Jaderi, F. et al. apply both traditional RBM and Fuzzy RBM (FRBM) methods for the risk analysis of petrochemical assets failure (Jaderi, 2018).

GAMM (Graphical Analysis for Maintenance Management) is a method that supports decisionmaking in maintenance management through the visualization and graphical analysis of reliability data (Mathew, 2017).

The oil industry has grown in terms of the number of facilities and process complexity. However, human and material losses still occur due to major accidents, including human failures. These failures can be identified, modeled and quantified through Human Reliability Analysis (Ramos, 2020).

The results show that the constructed model can provide effective guidance in the maintenance decision process. Compared with the perfect maintenance strategy, it highlights the costeffectiveness of the imperfect maintenance strategy (Shahin, 2018). 


\section{MATERIALS AND METHODS}

\section{Obtaining effective metrics in determining the equipment sensitivity index and its weighting Coefficient}

In the first stage, seven heads of petrochemical repairs in Tabriz (* Row 1) held a meeting and discussed this issue. It was concluded to specify sensitivity determination criteria and criticality of equipment using the Delphi method (Shasfand et al., 2016) and then be rated relative to each other. It was done. 10 criteria were selected, and 100 points were allotted among 10 criteria in comparison with each other. Then the issue was raised at numerous meetings (Tabriz petrochemicals expert meetings, Conference of status Monitoring in (Braglia, 2019), a training course in Spanish Seville University (Marquez, 2009), the twenty-seventh meeting of the maintenance managers of petrochemical in Iran, (Shasfand, 2017), the conference on condition monitoring of the University of Sharif in the Jam Petrochemical (Shasfand, 2017), and 12 $2^{\text {th }}$ ICPAM (Shasfand, 2017). The subject was raised, with a researcher's oral explanation, elites stated their comparative opinions verbally and also in written relevant forms with and without mentioning their names that researcher summarized the comments. Then using the AHP Group Decision Method and the formula $=\sqrt[k]{\prod_{k}\left(a i j^{k}\right)} i \mathrm{ij}, \quad \mathrm{a}_{\mathrm{ij}}=\mathrm{w}_{\mathrm{i}} / \mathrm{w}_{\mathrm{j}}$, (Asghar pours, 2015) paired comparison matrix was formed based on preferences of 75 specialists, and the result of calculations is listed in (Table 6). The group decision matrix was normalized and the weight of each of the ten elements was specified. Moreover, the compatibility dimension of the matrix was also calculated in which the results are presented.

\section{RESULTS AND DISCUSSION}

One of the primary criteria (Value added) that had been determined by seven heads of Tabriz petrochemicals using the Delphi method was deleted by the experts, and the operational risk was considered instead. In total, nine initial criteria and a new benchmark, 10 criteria were selected for determining the sensitivity of final equipment. Their weighting coefficients are shown in (Table 7) and formula 1 indicates the rate of equipment sensitivity. The specialists of each company, including maintenance, operation, technical services, and procurement and HSE departments, can give a score to each of the ten elements from 1 to 100 , and the scores can be placed in the formula to obtain the ECI. According to the scores obtained, the type of equipment sensitivity is determined based on the last column of (Table 8).

$\mathrm{ECI}=0.1155 \mathrm{Q}+0.0971 \mathrm{P}+0.0861 \mathrm{~A}+0.1025 \mathrm{R}+0.1158 \mathrm{C}+0.1047 \mathrm{M}+0.0908 \mathrm{O}+0.1185 \mathrm{~S}+0.0988 \mathrm{E}+0$. 0802EC (1)

Then, it is necessary to plan maintenance (Preventive maintenance, condition monitoring, predictive and corrective maintenance, determining the maximum and minimum required parts and reliability-based maintenance), technical inspection (determination of inspection periods, risk-based inspection and inspection program), procurement (Optimal Order Point) and operation of the necessary measures to suit the sensitivity. Type and leveling of ECI (Equipment Criticality Index) (A, B, C, D, and E) were achieved by 9 experts from different specializations as the brainstorm. Because of the anonymity of some judges as well as maintaining the confidentiality 
of experts' opinions, their alias names and job position were stated. Some data also were not fully explained due to limitations in the number of article pages.

Table 6: Paired comparison matrix based on preferences of 75 specialists using AHP group method

\begin{tabular}{|c|c|c|c|c|c|c|c|c|c|c|c|c|c|c|c|c|c|c|c|c|c|c|c|}
\hline No. & Judge & $\stackrel{\Xi}{\stackrel{\Xi}{\Xi}}$ & $\begin{array}{l}\stackrel{0}{0} \\
\stackrel{0}{0} \\
\stackrel{0}{0}\end{array}$ & 胥 & 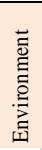 & 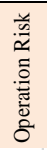 & 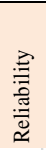 & 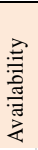 & 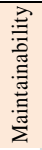 & 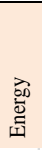 & $\vec{s}$ & No. & Judge & $\stackrel{\Xi}{\stackrel{\Xi}{\Xi}}$ & 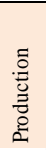 & 离 & 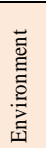 & 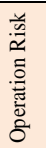 & 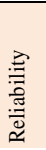 & 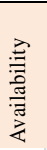 & 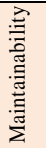 & $\begin{array}{l}\text { के } \\
\text { क्Dे } \\
\text { |= }\end{array}$ & $\overrightarrow{\tilde{\theta}}$ \\
\hline 1 & Main. Manag.*7 & 12 & 9 & 12 & 10 & 9 & 10 & 8 & 11 & 8 & 11 & 39 & Jam-DOPM & 13 & 10 & 10 & 9 & 10 & 12 & 10 & 10 & 7 & 10 \\
\hline 2 & Planning & 12 & 10 & 12 & 9 & 6 & 12 & 10 & 10 & 7 & 12 & 40 & JPC & 11 & 8 & 12 & 9 & 8 & 13 & 10 & 11 & 8 & 11 \\
\hline 3 & Mechanical & 12 & 11 & 11 & 10 & 9 & 10 & 7 & 11 & 8 & 12 & 41 & PPC & 10 & 10 & 14 & 12 & 8 & 11 & 12 & 5 & 6 & 12 \\
\hline 4 & $\mathrm{R} \& \mathrm{D}$ & 12 & 9 & 10 & 11 & 9 & 11 & 9 & 10 & 10 & 10 & 42 & MR-4 & 14 & 10 & 13 & 9 & 10 & 11 & 9 & 10 & 9 & 10 \\
\hline 5 & HRM & 12 & 10 & 11 & 9 & 11 & 9 & 10 & 10 & 9 & 9 & 43 & Razak MD & 12 & 10 & 10 & 10 & 10 & 10 & 9 & 10 & 9 & 10 \\
\hline 6 & DOCM & 11 & 12 & 8 & 10 & 13 & 11 & 8 & 12 & 8 & 9 & 44 & DOCM-Jam & 8 & 15 & 10 & 8 & 8 & 10 & 10 & 8 & 8 & 15 \\
\hline 7 & Percurment & 12 & 11 & 13 & 7 & 11 & 10 & 8 & 9 & 8 & 11 & 45 & MM1 & 8 & 8 & 15 & 10 & 15 & 10 & 9 & 15 & 10 & 15 \\
\hline 8 & Shift head & 12 & 10 & 11 & 8 & 10 & 10 & 9 & 12 & 10 & 9 & 46 & MM2 & 12 & 8 & 12 & 10 & 10 & 10 & 8 & 12 & 9 & 12 \\
\hline 9 & Feed head & 9 & 12 & 12 & 10 & 12 & 9 & 7 & 10 & 7 & 12 & 47 & MM3 & 10 & 10 & 14 & 8 & 8 & 10 & 10 & 12 & 8 & 10 \\
\hline 10 & $\mathrm{CM}$ & 10 & 10 & 12 & 11 & 9 & 10 & 8 & 10 & 10 & 10 & 48 & MOTS-KHPC & 15 & 7 & 12 & 8 & 8 & 10 & 10 & 8 & 8 & 10 \\
\hline 11 & IT & 11 & 8 & 14 & 13 & 9 & 8 & 12 & 11 & 8 & 7 & 49 & MOP-AKPC & 12 & 9 & 11 & 10 & 10 & 9 & 10 & 10 & 9 & 10 \\
\hline 12 & Electrical & 12 & 10 & 12 & 10 & 9 & 10 & 8 & 11 & 8 & 11 & 50 & MM4 & 10 & 10 & 14 & 10 & 6 & 10 & 8 & 12 & 7 & 11 \\
\hline 13 & SSD & 12 & 11 & 11 & 9 & 10 & 11 & 8 & 11 & 9 & 9 & 51 & MM5 & 12 & 9 & 11 & 9 & 9 & 10 & 9 & 8 & 10 & 13 \\
\hline 14 & DOM & 11 & 10 & 12 & 11 & 9 & 10 & 8 & 11 & 9 & 10 & 52 & MM6 & 12 & 9 & 12 & 10 & 9 & 12 & 6 & 11 & 8 & 11 \\
\hline 15 & Shift maneger & 15 & 8 & 11 & 12 & 8 & 9 & 9 & 10 & 8 & 11 & 53 & MM7 & 12 & 9 & 13 & 9 & 9 & 10 & 8 & 11 & 9 & 10 \\
\hline 16 & Security & 11 & 10 & 11 & 9 & 10 & 11 & 9 & 10 & 8 & 11 & 54 & MM8 & 12 & 10 & 13 & 10 & 9 & 10 & 10 & 12 & 7 & 12 \\
\hline 17 & Exc \&IT & 10 & 12 & 12 & 8 & 10 & 12 & 11 & 10 & 6 & 10 & 55 & MM9 & 10 & 11 & 12 & 8 & 9 & 12 & 10 & 11 & 8 & 11 \\
\hline 18 & Planning & 12 & 12 & 8 & 6 & 10 & 12 & 12 & 11 & 8 & 12 & 56 & MOM-KAPC & 10 & 10 & 13 & 11 & 10 & 10 & 10 & 10 & 8 & 10 \\
\hline 19 & Supervis our1 & 12 & 14 & 10 & 12 & 12 & 9 & 9 & 9 & 13 & 12 & 57 & DOMM-ARPC & 12 & 10 & 12 & 11 & 9 & 9 & 8 & 12 & 8 & 11 \\
\hline 20 & Supervisour2 & 12 & 11 & 10 & 8 & 9 & 11 & 9 & 10 & 10 & 13 & 58 & MM10 & 10 & 9 & 15 & 9 & 12 & 10 & 10 & 9 & 8 & 11 \\
\hline 21 & Supervisour3 & 15 & 15 & 8 & 12 & 10 & 8 & 8 & 8 & 6 & 12 & 59 & MM11 & 12 & 8 & 14 & 9 & 10 & 12 & 10 & 10 & 8 & 9 \\
\hline 22 & Supervis our4 & 10 & 10 & 15 & 15 & 11 & 15 & 1 & 10 & 10 & 5 & 60 & MM12 & 12 & 9 & 15 & 7 & 9 & 10 & 10 & 11 & 8 & 11 \\
\hline 23 & M.S.S1 & 12 & 10 & 14 & 10 & 10 & 10 & 6 & 10 & 9 & 10 & 61 & MM13 & 11 & 9 & 15 & 12 & 9 & 10 & 7 & 11 & 7 & 10 \\
\hline 24 & M.S.S2 & 12 & 9 & 12 & 9 & 9 & 10 & 11 & 10 & 8 & 11 & 62 & MM14 & 13 & 9 & 11 & 8 & 9 & 10 & 8 & 11 & 1 & 12 \\
\hline 25 & M.S.S3 & 18 & 9 & 12 & 10 & 4 & 10 & 8 & 11 & 7 & 11 & 63 & MOM-FBIPC & 10 & 9 & 10 & 11 & 10 & 9 & 8 & 12 & 10 & 11 \\
\hline 26 & M.S.S4 & 12 & 9 & 12 & 8 & 8 & 10 & 10 & 11 & 10 & 11 & 64 & BIPC & 11 & 8 & 15 & 12 & 8 & 10 & 8 & 10 & 8 & 10 \\
\hline 27 & M.S.S5 & 14 & 12 & 10 & 7 & 7 & 12 & 9 & 12 & 7 & 10 & 65 & MOM-REPC & 12 & 8 & 12 & 12 & 7 & 10 & 8 & 10 & 10 & 11 \\
\hline 28 & M.S.S6 & 14 & 8 & 10 & 10 & 10 & 10 & 10 & 12 & 5 & 10 & 66 & $\begin{array}{l}\text {-MOM } \\
\text { KHBIPC }\end{array}$ & 12 & 11 & 12 & 10 & 10 & 11 & 9 & 11 & 6 & 10 \\
\hline 29 & M.S.S7 & 12 & 9 & 12 & 11 & 8 & 10 & 8 & 11 & 9 & 9 & 67 & Pars MM & 12 & 9 & 12 & 10 & 9 & 10 & 8 & 11 & 7 & 12 \\
\hline 30 & M.S.S8 & 12 & 8 & 12 & 10 & 8 & 10 & 9 & 10 & 10 & 11 & 68 & ARYA_S_MM & 10 & 13 & 13 & 10 & 9 & 8 & 8 & 10 & 8 & 10 \\
\hline 31 & M.S.S9 & 12 & 10 & 12 & 10 & 8 & 10 & 7 & 11 & 11 & 9 & 69 & MM15 & 12 & 9 & 12 & 10 & 9 & 10 & 8 & 12 & 7 & 11 \\
\hline 32 & M.S.S10 & 12 & 11 & 12 & 10 & 10 & 11 & 8 & 8 & 8 & 9 & 70 & MM16 & 11 & 9 & 13 & 11 & 8 & 10 & 9 & 11 & 7 & 11 \\
\hline 33 & M.S.S11 & 12 & 11 & 12 & 10 & 10 & 11 & 8 & 10 & 8 & 8 & 71 & MS.S.A & 10 & 10 & 13 & 11 & 9 & 9 & 10 & 11 & 8 & 10 \\
\hline 34 & M.S.S12 & 12 & 8 & 12 & 10 & 8 & 11 & 9 & 11 & 8 & 11 & 72 & TRC-MM & 10 & 10 & 12 & 10 & 10 & 10 & 8 & 13 & 7 & 10 \\
\hline 35 & M.S.S13 & 13 & 9 & 12 & 10 & 9 & 10 & 9 & 12 & 8 & 11 & 73 & TRC-S-1 & 12 & 10 & 11 & 10 & 10 & 10 & 8 & 10 & 9 & 10 \\
\hline 36 & M.S.S14 & 10 & 10 & 12 & 10 & 9 & 10 & 9 & 12 & 8 & 11 & 74 & TRC-S-2 & 12 & 9 & 12 & 9 & 10 & 9 & 9 & 13 & 8 & 10 \\
\hline 37 & MR-1 & 9 & 12 & 10 & 12 & 9 & 10 & 11 & 8 & 11 & 8 & 75 & TRC-S-3 & 11 & 9 & 12 & 10 & 9 & 10 & 9 & 10 & 9 & 11 \\
\hline 38 & MR-2 & 10 & 5 & 10 & 22 & 5 & 10 & 10 & 10 & 10 & 20 & & & & & & & & & & & & \\
\hline
\end{tabular}


Table 7: Judgment of 75 specialists in the necessary characteristics to determine the sensitivity of the equipment

\begin{tabular}{|c|c|c|c|c|c|c|c|c|c|c|c|c|c|c|c|c|c|c|c|c|c|c|c|c|c|}
\hline \multirow[b]{2}{*}{0.12} & \multicolumn{8}{|c|}{ Normalized Matrix } & \multicolumn{2}{|c|}{ Sum } & \multicolumn{2}{|c|}{ Wi } & \multicolumn{9}{|c|}{ Matrix A } & \multicolumn{2}{|r|}{ Wi } & \multirow{2}{*}{$\begin{array}{l}A * W i \\
115.50\end{array}$} & \multirow{2}{*}{$\begin{array}{r}\lambda \text { maxi } \\
10.00\end{array}$} \\
\hline & 0.12 & 0.12 & 0.12 & 0.12 & 0.12 & 0.12 & 0.12 & 0.12 & 0.12 & 1.15 & 0.12 & 11.55 & 1.00 & 1.19 & 0.97 & 1.17 & 1.27 & 1.13 & 1.34 & 1.10 & 1.44 & 1.09 & 11.55 & & \\
\hline 0.10 & 0.10 & 0.10 & 0.10 & 0.10 & 0.10 & 0.10 & 0.10 & 0.10 & 0.10 & 0.97 & 0.10 & 9.71 & 0.84 & 1.00 & 0.82 & 0.98 & 1.07 & 0.95 & 1.13 & 0.93 & 1.21 & 0.92 & 9.71 & 97.13 & 10.00 \\
\hline 0.12 & 0.12 & 0.12 & 0.12 & 0.12 & 0.12 & 0.12 & 0.12 & 0.12 & 0.12 & 1.19 & 0.12 & 11.85 & 1.03 & 1.22 & 1.00 & 1.20 & 1.31 & 1.16 & 1.38 & 1.13 & 1.48 & 1.12 & 11.85 & 118.53 & 10.00 \\
\hline 0.10 & 0.10 & 0.10 & 0.10 & 0.10 & 0.10 & 0.10 & 0.10 & 0.10 & 0.10 & 0.99 & 0.10 & 9.88 & 0.86 & 1.02 & 0.83 & 1.00 & 1.09 & 0.96 & 1.15 & 0.94 & 1.23 & 0.93 & 9.88 & 98.78 & 10.00 \\
\hline 0.09 & 0.09 & 0.09 & 0.09 & 0.09 & 0.09 & 0.09 & 0.09 & 0.09 & 0.09 & 0.91 & 0.09 & 9.08 & 0.79 & 0.93 & 0.77 & 0.92 & 1.00 & 0.89 & 1.05 & 0.87 & 1.13 & 0.86 & 9.08 & 90.82 & 10.00 \\
\hline 0.10 & 0.10 & 0.10 & 0.10 & 0.10 & 0.10 & 0.10 & 0.10 & 0.10 & 0.10 & 1.02 & 0.10 & 10.25 & 0.89 & 1.05 & 0.86 & 1.04 & 1.13 & 1.00 & 1.19 & 0.98 & 1.28 & 0.97 & 10.25 & 102.46 & 10.00 \\
\hline 0.09 & 0.09 & 0.09 & 0.09 & 0.09 & 0.09 & 0.09 & 0.09 & 0.09 & 0.09 & 0.86 & 0.09 & 8.61 & 0.75 & 0.89 & 0.73 & 0.87 & 0.95 & 0.84 & 1.00 & 0.82 & 1.07 & 0.81 & 8.61 & 86.09 & 10.00 \\
\hline 0.10 & 0.10 & 0.10 & 0.10 & 0.10 & 0.10 & 0.10 & 0.10 & 0.10 & 0.10 & 1.05 & 0.10 & 10.47 & 0.91 & 1.08 & 0.88 & 1.06 & 1.15 & 1.02 & 1.22 & 1.00 & 1.31 & 0.99 & 10.47 & 104.65 & 10.00 \\
\hline 0.08 & 0.08 & 0.08 & 0.08 & 0.08 & 0.08 & 0.08 & 0.08 & 0.08 & 0.08 & 0.80 & 0.08 & 8.02 & 0.69 & 0.83 & 0.68 & 0.81 & 0.88 & 0.78 & 0.93 & 0.77 & 1.00 & 0.76 & 8.02 & 80.19 & 10.00 \\
\hline 0.11 & 0.11 & 0.11 & 0.11 & 0.11 & 0.11 & 0.11 & 0.11 & 0.11 & 0.11 & 1.06 & 0.11 & 10.58 & 0.92 & 1.09 & 0.89 & 1.07 & 1.17 & 1.03 & 1.23 & 1.01 & 1.32 & 1.00 & 10.58 & 105.82 & 10.00 \\
\hline & & & & & & & & & & 10 & & 100 & & $11-0$ & $\mathrm{Cl}=0$ & & Matri & 15 & прат & & & & $n=10$ & & \\
\hline
\end{tabular}

Table 8: Criteria, weighting coefficients and type of equipment sensitivity

\begin{tabular}{|c|c|c|c|c|c|c|c|c|c|c|}
\hline $\begin{array}{c}\text { No } \\
.\end{array}$ & Attribute & Type & $\begin{array}{c}\text { Weig } \\
\text { ht }\end{array}$ & Type & Attribute & $\begin{array}{c}\text { Typ } \\
\text { e }\end{array}$ & Weight & ECI & Type & Tactics \\
\hline 1 & Quality & Q & 11.55 & 6 & $\begin{array}{c}\text { Maintainabilit } \\
\text { y }\end{array}$ & M & 10.47 & $85-100$ & A & $\begin{array}{c}\text { RCM, RBI, CBM } \\
\text { TPM }\end{array}$ \\
\hline 2 & Production & $\mathrm{P}$ & 9.71 & 7 & $\begin{array}{c}\text { Operational } \\
\text { Risk }\end{array}$ & O & 9.08 & $67-84$ & B & CBM,TBM \\
\hline 3 & $\begin{array}{c}\text { Availabilit } \\
\text { y }\end{array}$ & A & 8.61 & 8 & Safety & S & 11.85 & $47-66$ & C & TBM, PM \\
\hline 4 & Reliability & $\mathrm{R}$ & 10.25 & 9 & Environment & E & 9.88 & $25-46$ & D & PM, Checking \\
\hline 5 & Cost & C & 11.58 & 10 & $\begin{array}{c}\text { Energy } \\
\text { Consumption }\end{array}$ & EC & 8.02 & $0-24$ & E & RTF \\
\hline
\end{tabular}

Formula for determination of resistance maintenance index

\section{Method 1:}

Researchers have introduced formula 2 to calculate the resistive maintenance index (RMI) of each company by studying articles, field studies and consult with experts.

$\mathrm{RMI}=\left(0.190 \sum_{\mathrm{i}=1}^{\mathrm{n}} \mathrm{OEE}_{\mathrm{i}}+0.202 \sum_{\mathrm{i}=1}^{\mathrm{n}} \mathrm{OLE}_{\mathrm{i}}+0.232 \sum_{\mathrm{i}=1}^{\mathrm{n}} \mathrm{EEE}_{\mathrm{i}}+0.182 \sum_{\mathrm{i}=1}^{\mathrm{n}} \mathrm{HSE}_{\mathrm{i}} \pm\right.$ $\left.0.194 \sum_{\mathrm{i}=1}^{\mathrm{n}} \mathrm{OCE}_{\mathrm{i}}\right) / \mathrm{n}$

According to the author, the maintenance of each company, especially the oil industry, is a function of the overall effectiveness of the equipment (OEE), overall labor effectiveness (OLE), reliance on internal capacity, endogeneity, extraversion, and exogeneity (EEE), compliance with health requirements, safety and Environment (HSE) and overall cost efficiency (OCE). The mentioned coefficient can be calculated for a sensitive device, a unit or even a complex. The researcher has used the opinions of 64 experts and AHP methodology to obtain the weighting 
coefficient of each of these components. The sample matrix of the preferences of Experts 1 and 30 is indicated in (Table 9). It is required to form a decision matrix based on a paired comparison of characteristics for 64 experts and then check their normalization and compatibility.

Summing up the preferences of the above-mentioned individuals is shown in (Table 10) in which the comments of some experts were accidentally hidden due to the space of the article.

The preferences matrix has been formed and normalized based on the Saaty method (group decisions). The component weights have also been extracted. According to the calculations, the matrix is consistent. Related data is indicated in (Table 11).

Table 9 :Sample matrix of paired comparison preferences of experts 1 and 30

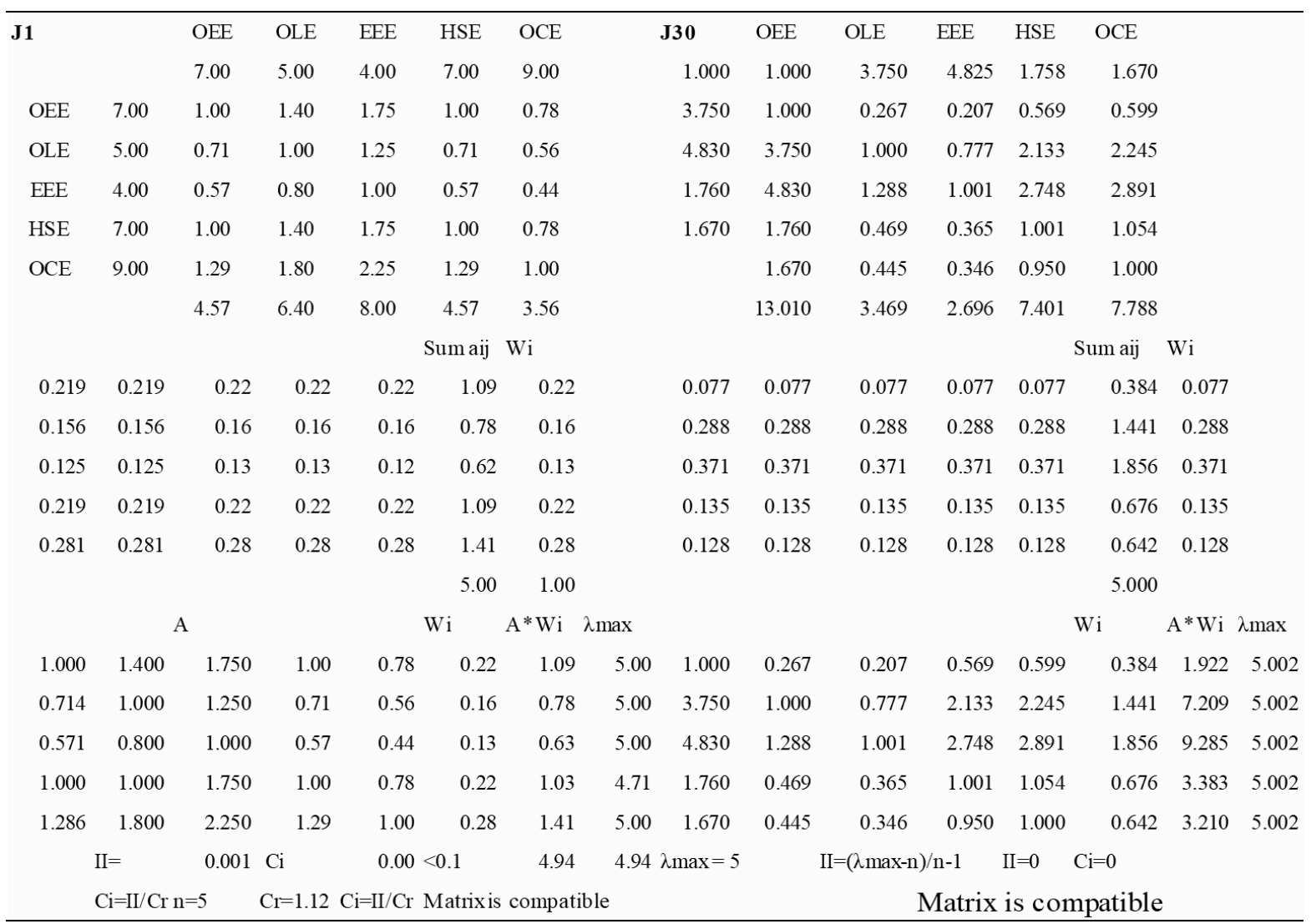

Table 10: Pairwise comparisons of preferences of 64 experts

\begin{tabular}{|l|l|l|l|l|l|l|l|l|l|l|l|l|l|}
\hline \multicolumn{2}{|l|}{ Judgment By } & O & O & E & H & O & Judgment By & O & O & E & H & O \\
& E & L & E & S & C & \multicolumn{2}{|l}{} & E & L & E & S & C \\
J1 & Inspection Head & 7 & 5 & 4 & 7 & 9 & J33 & Instrument Engineer & 3 & 5 & 7 & 5 & 9 \\
\hline J2 & Deputy of Complex M & 8 & 6 & 7 & 7 & 6 & J34 & Inspection Engineer & 7 & 4 & 6 & 4 & 4 \\
\hline J3 & Reliability Engineer & 7 & 9 & 9 & 6 & 8 & J35 & Workshop Manager & 3 & 5 & 7 & 5 & 8 \\
\hline J4 & Planning engineer & 8 & 8 & 9 & 7 & 7 & J36 & Instrument Manager & 4 & 4 & 6 & 5 & 4 \\
\hline
\end{tabular}




\begin{tabular}{|l|l|l|l|l|l|l|l|l|l|l|l|l|l|}
\hline J5 & Planning Manager & 9 & 7 & 5 & 7 & 9 & J37 & Professor & 9 & 4 & 6 & 5 & 9 \\
\hline J27 & Maintenance Ser. Manager & 4 & 4 & 6 & 5 & 4 & J59 & Plan. Manager-AKPC & 8 & 9 & 5 & 6 & 7 \\
\hline J28 & CM. Engineer & 3 & 5 & 6 & 3 & 3 & J60 & DOMM-ARPC & 5 & 4 & 6 & 3 & 3 \\
\hline J29 & Electrical Engineer & 4 & 4 & 6 & 4 & 4 & J61 & Eng. Manager-NPC & 4 & 4 & 6 & 4 & 4 \\
\hline J30 & Civil Engineer & 2 & 7 & 9 & 3 & 3 & J62 & Main. Manager-TPC & 4 & 4 & 6 & 4 & 3 \\
\hline J31 & Engineering Head & 3 & 4 & 6 & 5 & 5 & J63 & Main. Manager-Arya & 4 & 4 & 7 & 5 & 4 \\
\hline J32 & Machinery Engineer & 3 & 5 & 6 & 3 & 3 & J64 & Main. Manager-KHPC & 8 & 8 & 7 & 7 & 9 \\
\hline
\end{tabular}

Table 11: Matrix A based on paired comparison by AHP Method

\begin{tabular}{|c|c|c|c|c|c|c|c|}
\hline \multirow{2}{*}{$\begin{array}{l}\mathrm{a}_{\mathrm{ij}}=\mathrm{W}_{\mathrm{i}} / \mathrm{W}_{\mathrm{j}} \\
1.5312074681565 \mathrm{E}+47\end{array}$} & \multirow{2}{*}{$\begin{array}{l}\mathrm{a}^{1}{ }_{\mathrm{ij}} \\
5.461\end{array}$} & \multirow{2}{*}{$\sqrt[k]{\prod_{k}\left(a i j^{k}\right)}$} & \multicolumn{5}{|l|}{ Matrix A } \\
\hline & & & 5.460 & 5.800 & 6.620 & 5.240 & 5.570 \\
\hline $7.52863670331434 \mathrm{E}+48$ & 5.804 & 5.461 & 1.000 & 0.942 & 0.825 & 1.042 & 0.980 \\
\hline $3.5259881757892 \mathrm{E}+52$ & 6.623 & 5.804 & 1.062 & 1.001 & 0.877 & 1.108 & 1.042 \\
\hline $1.11529892555804 \mathrm{E}+46$ & 5.242 & 6.623 & 1.213 & 1.212 & 1.000 & 1.264 & 1.189 \\
\hline \multirow[t]{3}{*}{$5.39209024664604 \mathrm{E}+47$} & 5.569 & 5.242 & 0.960 & 0.903 & 0.792 & 1.000 & 0.941 \\
\hline & & 5.569 & 1.020 & 0.960 & 0.841 & 1.063 & 1.000 \\
\hline & & & 5.255 & 5.018 & 4.335 & 5.477 & 5.152 \\
\hline \multicolumn{5}{|c|}{ Normalize Matrix A } & Sum $a_{i j}$ & $\mathrm{Wi}=\mathrm{A}$ & \\
\hline 0.190 & 0.188 & 0.190 & 0.190 & 0.190 & 0.948 & 0.190 & OEE \\
\hline 0.202 & 0.199 & 0.202 & 0.202 & 0.202 & 1.008 & 0.202 & OLE \\
\hline 0.231 & 0.241 & 0.231 & 0.231 & 0.231 & 1.164 & 0.233 & EEE \\
\hline 0.183 & 0.180 & 0.182 & 0.183 & 0.183 & 0.910 & 0.182 & HSE \\
\hline 0.194 & 0.191 & 0.194 & 0.194 & 0.194 & 0.967 & 0.194 & OCE \\
\hline Is matrix compatible? & & A & & & $\mathrm{W}_{\mathrm{i}}$ & $\mathrm{A} * \mathrm{~W}_{\mathrm{i}}$ & $\lambda_{\max }$ \\
\hline 1.000 & 0.942 & 0.825 & 1.042 & 0.980 & 0.190 & 0.951 & 5.013 \\
\hline 1.062 & 1.001 & 0.877 & 1.108 & 1.042 & 0.202 & 1.011 & 5.327 \\
\hline 1.213 & 1.212 & 1.000 & 1.264 & 1.189 & 0.233 & 1.168 & 6.155 \\
\hline 0.960 & 0.903 & 0.792 & 1.000 & 0.941 & 0.182 & 0.913 & 4.811 \\
\hline \multirow[t]{3}{*}{1.020} & 0.960 & 0.841 & 1.063 & 1.000 & 0.194 & 0.970 & 5.113 \\
\hline & $\mathrm{II}=$ & 0.071 & $\mathrm{C}_{\mathrm{i}}=\mathrm{II} / \mathrm{Cr}$ & 0.063 & $\mathrm{C}_{\mathrm{i}}<0.1$ & & 5.284 \\
\hline & & $\operatorname{Cr}(5)=1.12$ & & Matrix is Compatible & & & \\
\hline
\end{tabular}

The second method,

The researcher formed a paired matrix of every 64 experts, determined the weight of every five components and calculated their compatibility. As an example, a portion of the calculation is presented in (Table 11). In the following, the results were placed in (Table 12) and the sum of the rows in a column (Sum) as well as the weight of each component was positioned in 64 rows of 5 columns based on each expert's opinion . Next, (Table 13) defines matrix B based on the group's 
decision formula by Mr. Saaty. According to the usual AHP method, the matrix was normalized, and each character's weight is presented in (Table 14). The weights obtained in the first and second methods (matrices A, B) were almost identical. Ultimately, according to (Table 15), the final weight was obtained by the researcher using the geometric mean, resistive index of maintenance is defined by formula 2 with these coefficients. Weight coefficients of EEE from the preferences of the experts were extracted based on the group AHP method and were listed in (Table 16). The weighting coefficients of HSE were assumed in relation to experts' opinions on safety, health and environment.

Table 12: A part of the 64 matrices formed based on the experts' preferences

\begin{tabular}{|l|l|l|l|l|l|l|l|l|l|l|l|l|l|l|l|}
\hline J6 & 8 & 1.00 & 0.21 & J2 & 8 & 1.00 & 0.24 & J4 & 8 & 1.00 & 0.21 & J5 & 9 & 1.00 & 0.24 \\
\hline & 9 & 1.13 & 0.24 & & 6 & 0.75 & 0.18 & & 8 & 1.00 & 0.21 & & 7 & 0.78 & 0.19 \\
\hline & 8 & 1.00 & 0.21 & & 7 & 0.88 & 0.21 & & 9 & 1.13 & 0.23 & & 5 & 0.56 & 0.14 \\
\hline & 7 & 0.88 & 0.18 & & 7 & 0.88 & 0.21 & & 7 & 0.88 & 0.18 & & 7 & 0.78 & 0.19 \\
\hline & 6 & 0.75 & 0.16 & & 6 & 0.75 & 0.18 & & 7 & 0.88 & 0.18 & & 9 & 1.00 & 0.24 \\
\hline & & $\mathbf{4 . 7 5}$ & & & & $\mathbf{4 . 2 5}$ & & & & $\mathbf{4 . 8 8}$ & & & & $\mathbf{4 . 1 1}$ & \\
\hline J3 & 7 & 1.00 & 0.18 & $\mathrm{j} 63$ & 4 & 1.00 & 0.17 & $\mathrm{j} 15$ & 8 & 1.00 & 0.23 & $\mathrm{~J} 40$ & 9 & 1.00 & 0.31 \\
\hline & 9 & 1.29 & 0.23 & & 4 & 1.00 & 0.17 & & 9 & 1.13 & 0.25 & & 4 & 0.44 & 0.14 \\
\hline & 9 & 1.29 & 0.23 & & 7 & 1.75 & 0.29 & & 5 & 0.68 & 0.15 & & 6 & 0.67 & 0.21 \\
\hline & 6 & 0.86 & 0.15 & & 5 & 1.25 & 0.21 & & 6 & 0.75 & 0.17 & & 5 & 0.56 & 0.17 \\
\hline & 8 & 1.14 & 0.21 & & 4 & 1.00 & 0.17 & & 7 & 0.88 & 0.20 & & 5 & 0.56 & 0.17 \\
\hline & & $\mathbf{5 . 5 7}$ & & & & $\mathbf{6 . 0 0}$ & & & & $\mathbf{4 . 4 3}$ & & & & $\mathbf{3 . 2 2}$ & \\
\hline J50 & 8 & 1.00 & 0.21 & J20 & 4 & 1.00 & 0.19 & $\mathrm{j} 44$ & 4 & 1.00 & 0.14 & J22 & 5 & 1.00 & 0.19 \\
\hline & 9 & 1.13 & 0.23 & & 4 & 1.00 & 0.19 & & 8 & 2.21 & 0.32 & & 4 & 0.90 & 0.17 \\
\hline & 8 & 1.00 & 0.21 & & 6 & 1.42 & 0.27 & & 6 & 1.58 & 0.23 & & 6 & 1.25 & 0.24 \\
\hline & 7 & 0.88 & 0.18 & & 4 & 1.00 & 0.19 & & 4 & 1.13 & 0.16 & & 5 & 1.11 & 0.21 \\
\hline & 7 & 0.88 & 0.18 & & 3 & 0.85 & 0.16 & & 4 & 1.07 & 0.15 & & 5 & 1.05 & 0.20 \\
\hline & & 4.88 & & & & 5.27 & & & & 7.00 & 1.00 & & & 5.30 & \\
\hline
\end{tabular}

Table 13: Obtaining the weight coefficients of the five sub-components of the formula of maintenance resistance

\begin{tabular}{|c|c|c|c|c|c|c|c|c|c|c|c|c|c|c|c|c|}
\hline & $\begin{array}{l}\text { OE } \\
\mathrm{E}\end{array}$ & $\begin{array}{l}\text { OL } \\
\mathrm{E}\end{array}$ & $\begin{array}{l}\mathrm{EE} \\
\mathrm{E}\end{array}$ & $\begin{array}{l}\text { HS } \\
\text { E }\end{array}$ & $\begin{array}{l}\mathrm{OC} \\
\mathrm{E}\end{array}$ & & & & & & $\begin{array}{l}\mathrm{Su} \\
\mathrm{m}\end{array}$ & $\mathrm{W}_{\mathrm{iA1}}$ & $\mathrm{W}_{\mathrm{iA} 2}$ & $\mathrm{~W}_{\mathrm{iA} 3}$ & $\mathrm{~W}_{\mathrm{iA4}}$ & $\mathrm{W}_{\mathrm{iA5}}$ \\
\hline $\mathrm{J} 1$ & 7 & 5 & 4 & 7 & 9 & $\begin{array}{l}1.0 \\
0\end{array}$ & $\begin{array}{l}0.7 \\
1\end{array}$ & $\begin{array}{l}0.5 \\
7\end{array}$ & $\begin{array}{l}1.0 \\
0\end{array}$ & $\begin{array}{l}1.2 \\
9\end{array}$ & $\begin{array}{l}4.5 \\
7\end{array}$ & $\begin{array}{l}0.43 \\
8\end{array}$ & $\begin{array}{l}0.31 \\
3\end{array}$ & $\begin{array}{l}0.25 \\
0\end{array}$ & $\begin{array}{l}0.43 \\
8\end{array}$ & $\begin{array}{l}0.56 \\
3\end{array}$ \\
\hline $\mathrm{J} 2$ & 8 & 6 & 7 & 7 & 6 & $\begin{array}{l}1.0 \\
0 \\
\end{array}$ & $\begin{array}{l}0.7 \\
5 \\
\end{array}$ & $\begin{array}{l}0.8 \\
8 \\
\end{array}$ & $\begin{array}{l}0.8 \\
8\end{array}$ & $\begin{array}{l}0.7 \\
5 \\
\end{array}$ & $\begin{array}{l}4.2 \\
5 \\
\end{array}$ & $\begin{array}{l}0.23 \\
5 \\
\end{array}$ & $\begin{array}{l}0.17 \\
6\end{array}$ & $\begin{array}{l}0.20 \\
6\end{array}$ & $\begin{array}{l}0.20 \\
6\end{array}$ & $\begin{array}{l}0.17 \\
6\end{array}$ \\
\hline $\begin{array}{l}\mathrm{J} 1 \\
6\end{array}$ & 4 & 4 & 6 & 5 & 4 & $\begin{array}{l}1.0 \\
0\end{array}$ & $\begin{array}{l}1.0 \\
1\end{array}$ & $\begin{array}{l}1.6 \\
2\end{array}$ & $\begin{array}{l}1.2 \\
7\end{array}$ & $\begin{array}{l}1.2 \\
1\end{array}$ & $\begin{array}{l}6.1 \\
1\end{array}$ & $\begin{array}{l}0.16 \\
4\end{array}$ & $\begin{array}{l}0.16 \\
6\end{array}$ & $\begin{array}{l}0.26 \\
5\end{array}$ & $\begin{array}{l}0.20 \\
8\end{array}$ & $\begin{array}{l}0.19 \\
8\end{array}$ \\
\hline $\begin{array}{l}\mathrm{J} 1 \\
8\end{array}$ & 4 & 4 & 6 & 9 & 3 & $\begin{array}{l}1.0 \\
0\end{array}$ & $\begin{array}{l}1.1 \\
2\end{array}$ & $\begin{array}{l}1.6 \\
5\end{array}$ & $\begin{array}{l}2.3 \\
4\end{array}$ & $\begin{array}{l}0.8 \\
4\end{array}$ & $\begin{array}{l}6.9 \\
5\end{array}$ & $\begin{array}{l}0.14 \\
4\end{array}$ & $\begin{array}{l}0.16 \\
1\end{array}$ & $\begin{array}{l}0.23 \\
8\end{array}$ & $\begin{array}{l}0.33 \\
7\end{array}$ & $\begin{array}{l}0.12 \\
1\end{array}$ \\
\hline $\begin{array}{l}\mathrm{J} 2 \\
8\end{array}$ & 3 & 5 & 6 & 3 & 3 & $\begin{array}{l}1.0 \\
0\end{array}$ & $\begin{array}{l}1.3 \\
3\end{array}$ & $\begin{array}{l}1.8 \\
2\end{array}$ & $\begin{array}{l}1.0 \\
0\end{array}$ & $\begin{array}{l}0.9 \\
5\end{array}$ & $\begin{array}{l}6.1 \\
1\end{array}$ & $\begin{array}{l}0.16 \\
4\end{array}$ & $\begin{array}{l}0.21 \\
8\end{array}$ & $\begin{array}{l}0.29 \\
8\end{array}$ & $\begin{array}{l}0.16 \\
4\end{array}$ & $\begin{array}{l}0.15 \\
6\end{array}$ \\
\hline $\begin{array}{l}\mathrm{J} 3 \\
1\end{array}$ & 3 & 4 & 6 & 5 & 5 & $\begin{array}{l}1.0 \\
0\end{array}$ & $\begin{array}{l}1.2 \\
0\end{array}$ & $\begin{array}{l}1.7 \\
4\end{array}$ & $\begin{array}{l}1.5 \\
4\end{array}$ & $\begin{array}{l}1.4 \\
6\end{array}$ & $\begin{array}{l}6.9 \\
4\end{array}$ & $\begin{array}{l}0.14 \\
4\end{array}$ & $\begin{array}{l}0.17 \\
3\end{array}$ & $\begin{array}{l}0.25 \\
0\end{array}$ & $\begin{array}{l}0.22 \\
2\end{array}$ & $\begin{array}{l}0.21 \\
1\end{array}$ \\
\hline $\begin{array}{l}\text { J4 } \\
5\end{array}$ & 7 & 5 & 4 & 7 & 9 & $\begin{array}{l}1.0 \\
0\end{array}$ & $\begin{array}{l}0.7 \\
1\end{array}$ & $\begin{array}{l}0.5 \\
7\end{array}$ & $\begin{array}{l}1.0 \\
0\end{array}$ & $\begin{array}{l}1.2 \\
9\end{array}$ & $\begin{array}{l}4.5 \\
7\end{array}$ & $\begin{array}{l}0.21 \\
9\end{array}$ & $\begin{array}{l}0.15 \\
6\end{array}$ & $\begin{array}{l}0.12 \\
5\end{array}$ & $\begin{array}{l}0.21 \\
9\end{array}$ & $\begin{array}{l}0.28 \\
1\end{array}$ \\
\hline
\end{tabular}




\begin{tabular}{|c|c|c|c|c|c|c|c|c|c|c|c|c|c|c|c|c|}
\hline $\begin{array}{l}\mathrm{J} 4 \\
7 \\
\end{array}$ & 7 & 9 & 9 & 6 & 8 & $\begin{array}{l}1.0 \\
0 \\
\end{array}$ & $\begin{array}{l}1.2 \\
9 \\
\end{array}$ & $\begin{array}{l}1.2 \\
9 \\
\end{array}$ & $\begin{array}{l}0.8 \\
6\end{array}$ & $\begin{array}{l}1.1 \\
4\end{array}$ & $\begin{array}{l}5.5 \\
7\end{array}$ & $\begin{array}{l}0.17 \\
9\end{array}$ & $\begin{array}{l}0.23 \\
1\end{array}$ & $\begin{array}{l}0.23 \\
1\end{array}$ & $\begin{array}{l}0.15 \\
4\end{array}$ & $\begin{array}{l}0.20 \\
5\end{array}$ \\
\hline $\begin{array}{l}\mathrm{J} 5 \\
0 \\
\end{array}$ & 8 & 9 & 8 & 7 & 7 & $\begin{array}{l}1.0 \\
0\end{array}$ & $\begin{array}{l}1.1 \\
3\end{array}$ & $\begin{array}{l}1.0 \\
0\end{array}$ & $\begin{array}{l}0.8 \\
8\end{array}$ & $\begin{array}{l}0.8 \\
8\end{array}$ & $\begin{array}{l}4.8 \\
8\end{array}$ & $\begin{array}{l}0.20 \\
5\end{array}$ & $\begin{array}{l}0.23 \\
1\end{array}$ & $\begin{array}{l}0.20 \\
5\end{array}$ & $\begin{array}{l}0.17 \\
9\end{array}$ & $\begin{array}{l}0.17 \\
9\end{array}$ \\
\hline $\begin{array}{l}\mathrm{J} 5 \\
1 \\
\end{array}$ & 7 & 8 & 6 & 6 & 8 & $\begin{array}{l}1.0 \\
0\end{array}$ & $\begin{array}{l}1.1 \\
4 \\
\end{array}$ & $\begin{array}{l}0.8 \\
6 \\
\end{array}$ & $\begin{array}{l}0.8 \\
6 \\
\end{array}$ & $\begin{array}{l}1.1 \\
4 \\
\end{array}$ & $\begin{array}{l}5.0 \\
0 \\
\end{array}$ & $\begin{array}{l}0.20 \\
0 \\
\end{array}$ & $\begin{array}{l}0.22 \\
9 \\
\end{array}$ & $\begin{array}{l}0.17 \\
1 \\
\end{array}$ & $\begin{array}{l}0.17 \\
1 \\
\end{array}$ & $\begin{array}{l}0.22 \\
9 \\
\end{array}$ \\
\hline $\begin{array}{l}\mathrm{J} 5 \\
4 \\
\end{array}$ & 9 & 8 & 77 & 6 & 5 & $\begin{array}{l}1.0 \\
0\end{array}$ & $\begin{array}{l}0.8 \\
9 \\
\end{array}$ & $\begin{array}{l}0.7 \\
8\end{array}$ & $\begin{array}{l}0.6 \\
7\end{array}$ & $\begin{array}{l}0.5 \\
6 \\
\end{array}$ & $\begin{array}{l}3.8 \\
9\end{array}$ & $\begin{array}{l}0.25 \\
7\end{array}$ & $\begin{array}{l}0.22 \\
9\end{array}$ & $\begin{array}{l}0.20 \\
0\end{array}$ & $\begin{array}{l}0.17 \\
1\end{array}$ & $\begin{array}{l}0.14 \\
3\end{array}$ \\
\hline $\begin{array}{l}\text { J5 } \\
9\end{array}$ & 8 & 9 & 5 & 6 & 7 & $\begin{array}{l}1.0 \\
0\end{array}$ & $\begin{array}{l}1.1 \\
3\end{array}$ & $\begin{array}{l}0.6 \\
8\end{array}$ & $\begin{array}{l}0.7 \\
5\end{array}$ & $\begin{array}{l}0.8 \\
8\end{array}$ & $\begin{array}{l}4.4 \\
3\end{array}$ & $\begin{array}{l}0.22 \\
6\end{array}$ & $\begin{array}{l}0.25 \\
4\end{array}$ & $\begin{array}{l}0.15 \\
4\end{array}$ & $\begin{array}{l}0.16 \\
9\end{array}$ & $\begin{array}{l}0.19 \\
7\end{array}$ \\
\hline $\begin{array}{l}\mathrm{J} 6 \\
0 \\
\end{array}$ & 5 & 4 & 6 & 3 & 3 & $\begin{array}{l}1.0 \\
0\end{array}$ & $\begin{array}{l}0.7 \\
9 \\
\end{array}$ & $\begin{array}{l}1.2 \\
1\end{array}$ & $\begin{array}{l}0.6 \\
9\end{array}$ & $\begin{array}{l}0.6 \\
6\end{array}$ & $\begin{array}{l}4.3 \\
4\end{array}$ & $\begin{array}{l}0.23 \\
0\end{array}$ & $\begin{array}{l}0.18 \\
1\end{array}$ & $\begin{array}{l}0.27 \\
9\end{array}$ & $\begin{array}{l}0.15 \\
9\end{array}$ & $\begin{array}{l}0.15 \\
1\end{array}$ \\
\hline $\begin{array}{l}\text { J6 } \\
4\end{array}$ & 8 & 8 & 7 & 7 & 9 & & $\begin{array}{l}1.0 \\
0\end{array}$ & $\begin{array}{l}0.8 \\
8\end{array}$ & $\begin{array}{l}0.8 \\
8\end{array}$ & $\begin{array}{l}1.1 \\
3\end{array}$ & $\begin{array}{l}4.8 \\
8\end{array}$ & $\begin{array}{l}0.20 \\
5\end{array}$ & $\begin{array}{l}0.20 \\
5\end{array}$ & $\begin{array}{l}0.17 \\
9\end{array}$ & $\begin{array}{l}0.17 \\
9\end{array}$ & $\begin{array}{l}0.23 \\
1\end{array}$ \\
\hline
\end{tabular}

Table 14: Matrix B on the basis of group decisions with geometric mean

\begin{tabular}{|c|c|c|c|c|c|c|c|}
\hline $3.4962108124665 \mathrm{E}-47$ & & 0.188 & 1.00 & 0.94 & 0.82 & 1.04 & 0.98 \\
\hline $1.71901597873931 \mathrm{E}-45$ & & 0.200 & 1.06 & 1.00 & 0.88 & 1.11 & 1.04 \\
\hline $8.05089985595818 \mathrm{E}-42$ & & 0.228 & 1.21 & 1.14 & 1.00 & 1.26 & 1.19 \\
\hline $2.5465655332539 \mathrm{E}-48$ & & 0.180 & 0.96 & 0.90 & 0.79 & 1.00 & 0.94 \\
\hline $1.23117765646845 \mathrm{E}-46$ & & 0.192 & 1.02 & 0.96 & 0.84 & 1.06 & 1.00 \\
\hline & & & 5.255 & 4.945 & 4.33 & 5.47 & 5.15 \\
\hline
\end{tabular}

Table 15: Normalized matrix B and weight coefficients of the five sub criteria

\begin{tabular}{|c|c|c|c|c|c|c|c|c|c|c|c|c|c|c|}
\hline & & Norm & & & $\operatorname{Sum}\left(\mathrm{a}_{\mathrm{ij}}\right)$ & Wi-B & & & $\mathrm{B}$ & & & $\mathrm{W}_{\mathrm{i}} \mathrm{B}$ & $\mathrm{B} * \mathrm{~W}_{\mathrm{i}} \mathrm{B}$ & $\lambda_{\max }$ \\
\hline 0.190 & 0.190 & 0.190 & 0.190 & 0.190 & 0.952 & 0.190 & 1.000 & 0.941 & 0.825 & 1.042 & 0.981 & 0.190 & 0.951 & 5.000 \\
\hline 0.202 & 0.202 & 0.202 & 0.202 & 0.202 & 1.012 & 0.202 & 1.063 & 1.000 & 0.876 & 1.107 & 1.042 & 0.202 & 1.011 & 5.314 \\
\hline 0.231 & 0.231 & 0.231 & 0.231 & 0.231 & 1.154 & 0.231 & 1.213 & 1.141 & 1.000 & 1.263 & 1.189 & 0.231 & 1.154 & 6.064 \\
\hline 0.182 & 0.183 & 0.183 & 0.183 & 0.183 & 0.914 & 0.183 & 0.960 & 0.903 & 0.791 & 1.000 & 0.941 & 0.183 & 0.913 & 4.799 \\
\hline 0.194 & 0.194 & 0.194 & 0.194 & 0.194 & 0.971 & 0.194 & 1.020 & 0.960 & 0.841 & 1.062 & 1.000 & 0.194 & 0.970 & 5.099 \\
\hline 0.999 & 1.001 & 1.001 & 1.001 & 1.001 & 5.002 & 1.000 & $\mathrm{II}=$ & \multicolumn{2}{|c|}{$\left(\lambda_{\max }-n\right) / 4$} & 0.064 & $\mathrm{C}_{\mathrm{i}}=\mathrm{II} / \mathrm{Cr}$ & 0.057 & $<0.1$ & 5.255 \\
\hline & & & & & & & & & \multicolumn{3}{|c|}{ Matrix is compatible } & & & \\
\hline
\end{tabular}

Table 16: Final weighting coefficients obtained from geometric mean

\begin{tabular}{|l|c|c|l|l|l|}
\hline \multicolumn{1}{|c|}{$\mathrm{B}$} & $\mathrm{A}$ & $\mathrm{B} * \mathrm{~A}$ & \multicolumn{2}{c|}{ SQRT(B) } & \\
\hline 0.190 & 0.190 & 0.036 & 0.190 & OEE & A1 \\
\hline 0.202 & 0.202 & 0.041 & 0.202 & OLE & A2 \\
\hline 0.231 & 0.233 & 0.054 & 0.232 & EEE & A3 \\
\hline 0.183 & 0.182 & 0.033 & 0.182 & HSE & A4 \\
\hline 0.194 & 0.194 & 0.038 & 0.194 & OCE & A5 \\
\hline
\end{tabular}

OEE $=$ Overall Equipment Effectiveness $=$ Availability $*$ performance $*$ quality $($ Gupta \& Garg, 2012), OLE $=$ Overall labor Effectiveness $=$ Availability $*$ performance $*$ quality

$\mathrm{EEE}=$ Endogeneity $\left(\mathrm{E}_{1}\right)$, Extroversion $\left(\mathrm{E}_{2}\right)$, Exogeneity $\left(\mathrm{E}_{3}\right)($ Shasfand \& Seyed Hosseini, 2016) 
Weight coefficients of EEE from the preferences of the experts were extracted based on group AHP method and were listed in (Table 17).

Table 17: Weighting coefficients of endogeneity, extroversion and exogeneity

\begin{tabular}{|l|l|l|l|l|l|l|l|l|l|l|l|l|l|l|l|}
\hline EEE & & $\mathbf{A}$ & & & & & Sum & $\mathbf{W}_{\mathbf{i}}$ & & $\mathbf{A H P}$ & $\mathbf{A}$ & & $\mathbf{W}_{\mathbf{i}}$ & $\mathbf{A}^{* \mathbf{W}}$ & $\lambda_{\max }$ \\
\hline Endogeneity & 1.00 & 2.00 & 4.00 & 0.57 & 0.63 & 0.54 & 1.74 & 0.583 & $\mathrm{~W} 1$ & 1.00 & 2.20 & 3.80 & 0.583 & 1.76 & 3.01 \\
\hline Extroversion & 0.50 & 1.00 & 2.00 & 0.26 & 0.29 & 0.21 & 0.76 & 0.254 & $\mathrm{~W} 2$ & 0.45 & 1.00 & 1.50 & 0.254 & 0.76 & 3.00 \\
\hline Exogeneity & 0.25 & 0.50 & 1.00 & 0.15 & 0.19 & 0.14 & 0.48 & 0.162 & $\mathrm{~W} 3$ & 0.26 & 0.67 & 1.00 & 0.162 & 0.48 & 3.00 \\
\hline & 1.75 & 3.50 & 7.00 & & & & 2.99 & 1.00 & & $\mathrm{II}=\left(\lambda_{\max }-\mathrm{n}\right) / \mathrm{n}-1$ & $\mathrm{II}=0$ & $\begin{array}{l}\mathrm{C}_{\mathrm{i}}=\mathrm{II} / \mathrm{Cr}=0 \\
\text { Compatible }\end{array}$ & \\
\hline
\end{tabular}

$$
E E E=\left(\sum_{i=1}^{n}\left(\sum_{j=1}^{5}\left(0.583 E_{1_{i j}}+0.254 E_{2 i j}+0.162 E_{3 i j}\right)\right) / 5\right) / n
$$

$\mathrm{J}$ : Human, Equipment, Knowledge, management, criteria $=5$

The weighting coefficients of HSE were assumed in relation to experts' opinion on safety, health and environment.

$$
\begin{gathered}
\mathrm{HSE}=\text { Health, Safety \& Environment }=\left(\left(\mathrm{W}_{\mathrm{H}} * \mathrm{H}_{\mathrm{i}}\right)+\left(\mathrm{W}_{\mathrm{s}} * \mathrm{~S}_{\mathrm{i}}\right)+\left(\mathrm{W}_{\mathrm{E}} * \mathrm{E}_{\mathrm{i}}\right)\right) \\
\mathrm{W}_{\mathrm{H}}=0.308, \mathrm{~W}_{\mathrm{S}}=0.384, \text { and } \mathrm{W}_{\mathrm{E}}=0.308 \\
H S E=\left(\sum_{i=1}^{n}\left(0.308 H_{i}+0.384 S_{i}+0.308 E_{i}\right)\right) / n
\end{gathered}
$$

OCE $=$ Overall Cost Efficiency=Total maintenance cost $/$ Total Maintenance Budget (Roda \& Garetti, 2015)

If OCE $\leq 1$ therefore use $(+), \mathrm{OCE}>1$, then use [-(1-OCE)]

\section{CONCLUSION}

Preservation of national capital and continuous improvement in the oil, gas, refinement, and petrochemical industries is one of the strategic goals of the oil ministry. Due to resource constraints and the existence of millions of equipment pieces in the oil-based companies, identification, categorization, monitoring, and care of critical equipment is crucial. A model and index for resistive maintenance is also essential in the country's current state. Therefore, researchers of the paper have introduced two practical formulas related to the determination of equipment sensitivity index as well as sustainability levels and resistance of maintenance system by studying the relevant published articles, examining objective evidence, benefitting from the perspectives of experts that can cause the development of industries, especially the oil industry. In the following, it is required to work on effective indicators in measuring the performance of resistive maintenance. 


\section{CONFLICTS OF INTEREST}

The authors declare that they have no conflicts of interest.

\section{REFERENCES}

Asghar pours, M. (2015), "Multi criteria Decision Making", 14th, Tehran University press, 16(4): 26-37.

Assaf, S. (2014). "Performance evaluation and benchmarking for ... at Petrochemical corporation using a DEA model", Int. J adv. Manuf. Technol., Springer, London, 22(4): 36-19.

Assaf, S. (2014), "Performance evaluation and benchmarking for ... at Petrochemical corporation using a DEA mode", Int J adv Manuf Technol, Springer, London, 9(3): 26-33.

Bitaraf, H. (2017). "Physical Asset Management in Petroleum ministry", 12th ICPAM-IPAMC, Tehran, Iran, 14(1): 14-15.

Blischke, W., \& Murthy, D. (2003). 'Case studies in Reliability and Maintenance', Wiley, New Jersey, 34(6): 174-186.

Braglia, M. (2019). "a novel operational approach to equipment maintenance: TPM and RCM jointly at work", journal of quality in maintenance engineering, 6(3): 44-57.

Charaf, K., \& Ding, H. (2015). "Is overall Equipment effectiveness (OEE) universally Applicable", International journal of Economics and Finance, 7(2): 125-140.

Chia Chien, H. (2007). "The Delphi Technique: Making Sense of Consensus, Practical Assessment, Research \& Evaluation", 12(10): 59-76.

Gupta, A., \& Garg, K. (2012). "OEE Improvement by TPM Implantation A case study", IJIEASR, 12(4): 74-80.

Jaderi, F. (2018). "Criticality Analysis of Petrochemical Assets using Risk Based Maintenance and the Fuzzy Inference System", Process Safety and Environmental Protection, 19(1): 200-215.

Kareem, B., \& Jewo, O. (2015). "Development of a model for Failure prediction on critical equipment in the petrochemical industry", Elsevier, 18(5): 129-137.

Lindberg, S. (2015). "Key performance indicators improve industrial performance", ICAE, Energy procedia, 7(5): 1785-1790.

Marquez, A. (2009). "The Maintenance management farm work", JQME, 15(2): 167-178.

Mathew, J. (2017). "Asset Intelligence through Integration and Interoperability and Contemporary Vibration Engineering Technologies", Lecture Notes in Mechanical Engineering, 16(4): 70-89.

Parida, A. (2015). "Performance measurement and Management for Maintenance", JQME, 21(4): 191209. 
Ramos, M. (2020). "A human reliability analysis methodology for oil refineries and petrochemical plants operation: Phoenix-PRO qualitative framework, Reliability Engineering and System Safety, 15(2): 193204.

Roda, I., \& Garetti, M. (2015). Application of Performance driven total cost of owner ship (TCO), evaluation model for physical asset management", 26(4): 319-342.

Seyed Hosseini, S. (2011). "Introduction to the inclusive maintenance", Tehran: Iran, 16(5): 124-136.

Shahin, A. (2018). "Developing a Decision Making Grid for determining proactive maintenance tactics: A case study in the steel industry", Journal of Manufacturing Technology Management, 14(3): 48-60.

Shasfand, S., \& Alipour, M. (2003). "Comparing achieved data from implementing of CMMS in Cheil(S.Korea) and Iran petrochemicals", 2nd National Conference on Maintenance, IUST, Tehran, Iran, 15(3): 410-427.

Shasfand, S., \& Seyed Hosseini, S. (2016). "Enlightening Resistive Production", MCSER, 7(4): 148-160.

Shasfand, S. (2017). "OEE \& Reliability in Petrochemical industries", 12th ICPAM- IPAMC, 11(8): 1425.

Shasfand, S., Seyed Hosseini, M., \& Shahanaghi, K. (2016). "Increasing reliability and availability in a gas turbine generator by using RCM",13th conference on CM \& MFPT, October, 6(3): 110-119.

Shasfand, S. (2017). "OEE \& Reliability in Petrochemical industries", 12th ICPAM-IPAMC, Tehran, Iran, 13(1): 14-15.

Shasfand, S., \& Seyed Hosseini, S. (2016). Enlightening Resistive Production, MCSER, 7(4): 33(4): $112-$ 124.

Shasfand, S. (2017). "Resistive Maintenance", 27th meeting of petrochemicals maintenance managers (NPC), Mashhad, Iran, pp: 65-69.

Simoes, J. (2011). "A literature review of maintenance performance measurement", QME, 17(2): 116137.

Sivaram, N. (2013). "Implementing total productive maintenance through the ISO9001: 2008", SAJIE, 24(2): 33-46.

Stevens, B. (2017). "Continuous Maintenance Improvement Roadmap", 12th ICPAM-IPAMC, Tehran: Iran, 18(4): 14-15.

Wang, Q. (2011), "Development and application of equipment maintenance and Safety integrity management system", JLP, Elsevier., 15(2): 312-323.

Wireman, T. (2004). "Benchmarking best practices in maintenance", Industrial press Inc, New York, USA, 14(9): 208-225.

Zuashkiani, A. (2011). "Methodology and theory mapping the dynamics of OEE", JQME, 17(1): 74-92. 